\title{
MAPPING VOTES for VOTING GENERAL ELECTIONS MEMBERS of THE HOUSE REPRESENTATIVES, and REGIONAL HOUSE REPRESENTATIVES in SUKOHARJO SUB-DISTRICT, SUKOHARJO DICTRICT 2019.
}

\author{
Bowo Setiawan $^{1}$, Agus Sudargono ${ }^{2}$, Pranichayudha $\mathrm{R}^{3}$ \\ 1,2,3 Geography Education, Universitas Veteran Bangun Nusantara \\ Email : Bowosetiawan55@gmail.com
}

\begin{abstract}
This research aims to distribution of general voting pleaces member of the house of representative and regional people's representative asembly on sukoharjo sub-district and sound calculation results political parties general election participants member of the house of representative and regional people's representative assembly every pleace of voting votes in Sukoharjo sub-districtSukoharjo district's. This report uses quantitative descritive that is disclosure and know the location point spreads

of general election places members of the house of representative and regional people's representative assembly 2019. And resuilts of sound calculations every political party every place voting around sukoharjo sub-district, data colection techniques used are are through direct observation in te field, and documentation data analysis techniques used are analysis of table and data map. This research results are spreadd of spot vocational places in sukoharjo sub-district. There are 252 sound vocational places spreads in 14 areas set by the commission of general elections accordingto many population in every way, the most amount of the most vocational place is Sukoharjo cheap and Gayam cheap each with 27 sound vocational place, and the little area of number of sound votes Combongan cheap with 13 sound vocation place general election member of the house of representative, in the level of the people's representative of the republic of indo the provincial people's representativf council and the district representative concil in the sukoharjo sub-district dominated by PDIP parties
\end{abstract}

Keywords: distribution, voting place house of representative, regional people's representatif assembly, Party

\section{INTRODUCTION}

General election is meant as mechanism of selection system and delegation or sovereignty transference to people or party which is believed, however the writer determines the definition of general election as stated in Law Number 8 of 2012 article 1 paragraph (1) the mean of General Election is a means of exercising people's sovereignty in the Unitary State of the Republic of Indonesia based on Pancasila and The Constitution of the Republic of Indonesia of the year 1945 . 
In reacing simultaneous election in 2019 based on Constitutional Court Decree No.14/PU$\mathrm{XI} / 2013$ about concerning the simultaneous election, an interpretation emerged that the 2019 elections would be held in 5 box. In simple terms the decision was widely understood as the diversivication in the administration where the 2019 elections would be held simultaneously to elect the House of Representatives, Regional Representative Board, Regional House of Representatives and Vice President.

The implementation of general election aims to elect the members of the House of Representatives, Regional House of Representatives Province, and Regional House of Representative Regency which is called as general legislative election. For the Indonesian Legislative Election and Presidential Election 2019, from 27 parties that registered there are only 14 parties which completed administratives requirement and factual verification while the amount of the electors in Daftar Pemilih Tetap/DPT (Final Voter List) General Elections Comission, noted as many as $\mathbf{1 8 5 . 7 3 2 . 0 9 3}$ people which consist of 92.802 .671 men and 92.929.422 women which will elect in 805.075 polling stations.

The existence of Polling Station (TPS) in Sukoharjo sub-district is a form of facility provided by the General Elections Comission in carrying out the duties and obligations of the General Elections Comission, the existence of Polling Station is needed by the community to give their rights of voting in participating in the general election held by the General Elections Comission. In determining the Polling Stations (TPS) the Regional General Elections Comission of Sukoharjo formed 252 Polling Stations in the Sukoharjo District which spread in 14 Urban Villages. The number of Polling Stations in each Urban Villages is adjusted to the number of voters where each voter in the Polling Station does not exceed 300 voters.

This study aims to determine the distribution of Polling Stations provided by General Elections Comission to hold general elections of the House of Representatives, the Regional House of Representatives Province, and the Regional House of Representatives Regency of Sukoharjo.

\section{RESEARCH METHOD}

The method used is the Sampling Quota Method that can be obtained by electing the sample members conducted against anyone who is met until the amounts is met in accordance with the predetermined quota. In this study, the researcher wants to gain the information by contacting respondents obtained from user manuals that are useful for knowing 
predetermined respondents (2013: 152). In this study, the researcher obtains the data that becomes the sample made by General Elections Comission of Sukoharjo Regency.

Data sources in the research are subjects from which data can be obtained. The data from this study are classified into two which are primary data and secondary data, Primary Data (first hand data) Primary Data is a data source that directly provides data to data collectors (Sugiyono, 2015: 255). Obtained directly from research subjects by using measurement tools or data collection tools directly on the subject as a source of Information sought.

In taking this primary data, researcher obtains by direct interview with parties related to the pbject of research, including the researchercoming directly to the Polling Station to collect data related to the number of votes and the results of the vote count each Polling Station, then the researcher asks the data to the General Elections Comission of Sukoharjo Regency. Secondary data (second hand data), secondary data is a data source that does not necessarily provide data to data collectors, for example through other people or documents (Sugiono, 2015:225). This data is in the form of documents, the reports that have been available and so on. In this research, researcher has classified or classified data sources according to the types of data sources that have been formulated, including: Primary Data, is a data obtained directly from the object of research, obtained through field surveys/observations and interviews. Whereas Secondary Data is the data which is obtained indirectly from research objects obtained from relevant books/literature, scientific journals, documentation, thesis, Central Bureau of Statistic, General Elections Comission and others as well as laws related to its research.

\section{RESULTS}

a. The distribution of polling stations of general elections of the House of Representatives (DPR), the Regional House of Representatives Province (DPD), and the Regional House of Representatives Regency of Sukoharjo (DPRD)

The analysis used to know the distribution of polling station of general elections of the House of Representatives, the Regional House of Representatives Province, and the Regional House of Representatives Regency of Sukoharjo is the spatial analysis using map. In this study, map is used as the media to present locational information of polling stations that are represented in point symbol. From this locational points, the distribution of polling stations will be revealed. 
The location of polling station in Sukoharjo Sub District is a facility that is provided by general election comisssion (KPU) in conducting their obligation to held general election. This polling station is important as a place for citizens to give their aspiration in general election held by KPU. There are 252 polling stations in Sukoharjo that are spread in 14 hamlets and its determination is set to the amount of people in which each station should not exceed of 300 inhabitants.

The number of polling stations in Sukoharjo Sub-district is 252 that is spread over 14 villages. The distribution of those polling stations is served in Figure 1.

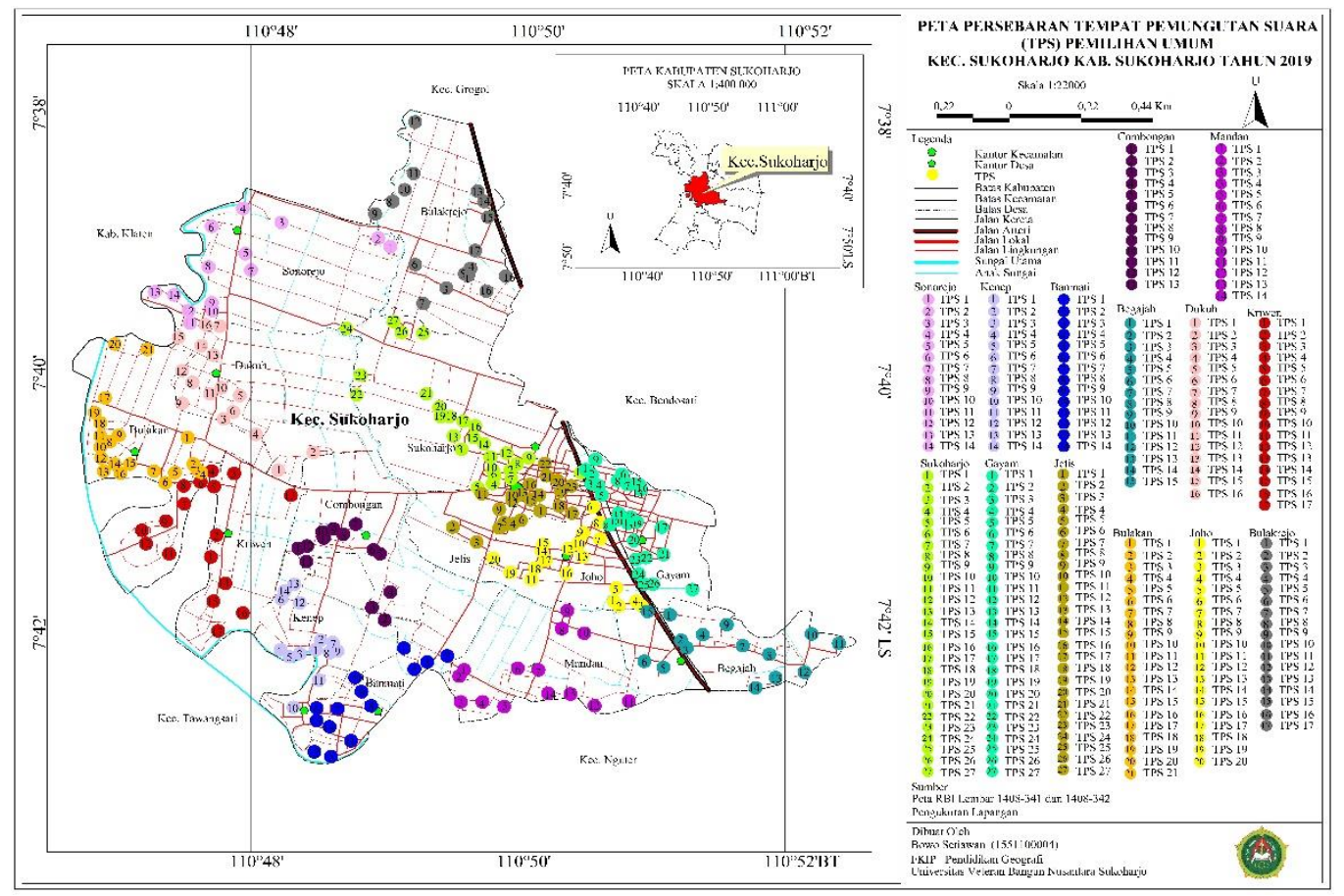

Figure 1. The Distribution of polling stations in Sukoharjo Sub-district

The map shows that the location of polling stations in Sukoharjo is situated at the village that has large number of people. Some places that are used as the polling stations are local inhabitant house, school, hall, and meeting room. The hamlet that has the largest number of polling station is Sukoharjo and Gayam village whose 27 locations on each village, while the least is Combongan village with 13 polling stations. More detailed information is described as follows : Sukoharjo village 27 stations, Gayam village 27 stations, Jetis village 23 stations, Bulakan village 21 stations, Joho village 20 stations, Kriwen village 17 stations, Bulakrejo village 17 stations, Dukuh village 16 stations, 
Begajah 15 village stations, Banmati village 14 stations, Mandan village 14 stations, Sonorejo village 14 stations, Kenep village 14 stations, Combongan village 13 stations.

b. The voting result of political parties in general election of Sukoharjo SubRegency through map

From the voting result of general elections of the House of Representatives, the Regional House of Representatives Province, and the Regional House of Representatives Regency of Sukoharjo there are similarity and difference in each polling station for each party. To create a map, the results of voting results of general elections will be gathered (Figure 2).

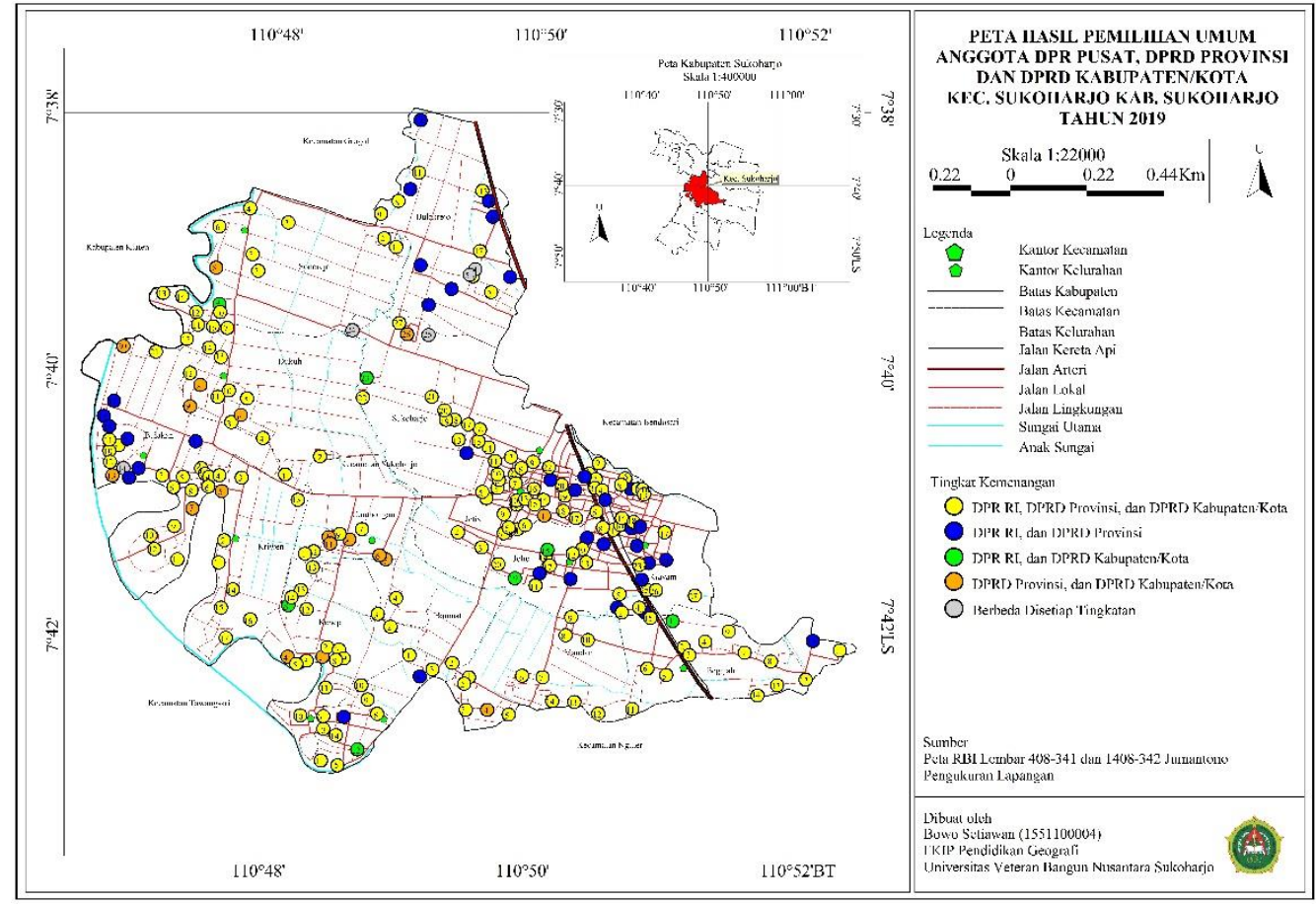

Figure 2. The Map of General Election Voting Result of the House of Representatives, the Regional House of Representatives Province, and the Regional House of Representatives Regency of Sukoharjo

From the map, it can be seen that the voting result of general election is symbolyzed in different colour as described below :

1) Yellow dot represents the similarity of the highest vote in DPR RI, DPRD (province), DPRD (regency) in the same party;

2) Blue dot represents the similarity of the highest vote in DPR RI and DPRD (province) in the same party; 
3) Green dot represents the similarity of the highest vote in DPR RI and DPRD (regency) in the same party;

4) Orange dot represents the similarity of the highest vote in DPRD (province) and DPRD (regency) in the same party;

5) Grey dot represents the difference of the highest vote in DPR RI, DPRD (province), DPRD (regency).

Additionally, Table 1 is served to see the highest vote of the same party in all levels of general election based on the number of polling station.

Table 1. The result of general election for the same party

\begin{tabular}{|l|l|l|l|}
\hline No & General Election & Symbol & Polling Stations \\
\hline 1 & DPR RI, DPRD (Province) and DPRD (Regency) & Yellow & 160 \\
\hline 2 & DPR RI and DPRD (province) & Blue & 36 \\
\hline 3 & DPRD (province) and DPRD (regency) & Orange & 17 \\
\hline 4 & DPR RI and DPRD (Regency) & Green & 7 \\
\hline 5 & DPR RI, DPRD (province), DPRD (regency) & Grey & 5 \\
\hline \multicolumn{2}{|l}{ Total } & 252 \\
\hline
\end{tabular}

From table 1, it can be seen that there are 160 polling stations that acquire the top vote for the same party in all levels of general election, while there are 36 polling stations in which the same party obtains highest score in DPR RI and DPRD (province). Moreover, there are 17 polling stations that attains the uppermost result in DPRD (province) and DPRD (regency) for the same party and 7 polling stations that obtains the highest result in DPR RI and DPRD (Regency) for the similar party. On the other hand, the highest vote in 5 polling stations in all levels of general election is obtained by different party. The party that gains the top vote in all levels of general election is PDIP that is followed by other parties such as PKB, GERINDRA, GOLKAR, and NASDEM. 
The information that shows this result is presented in figure 3 .

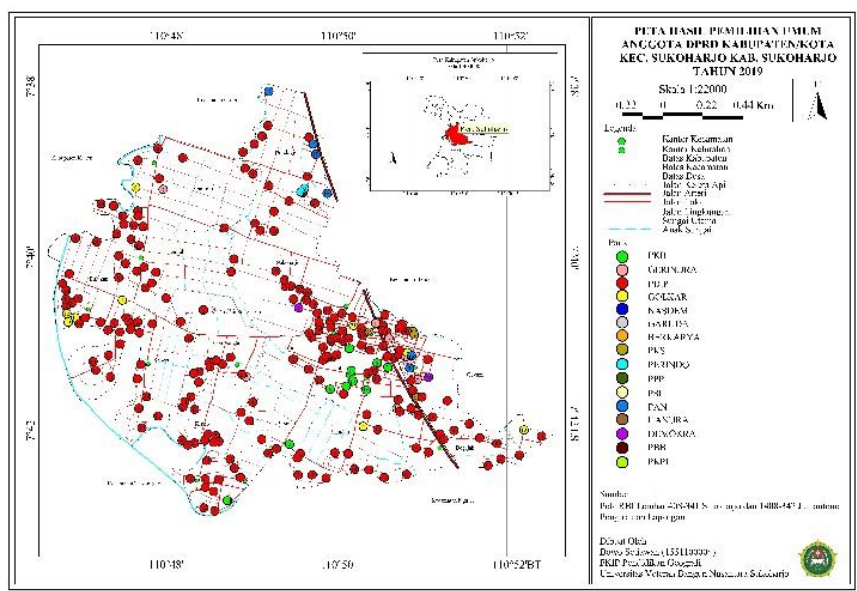

(a)

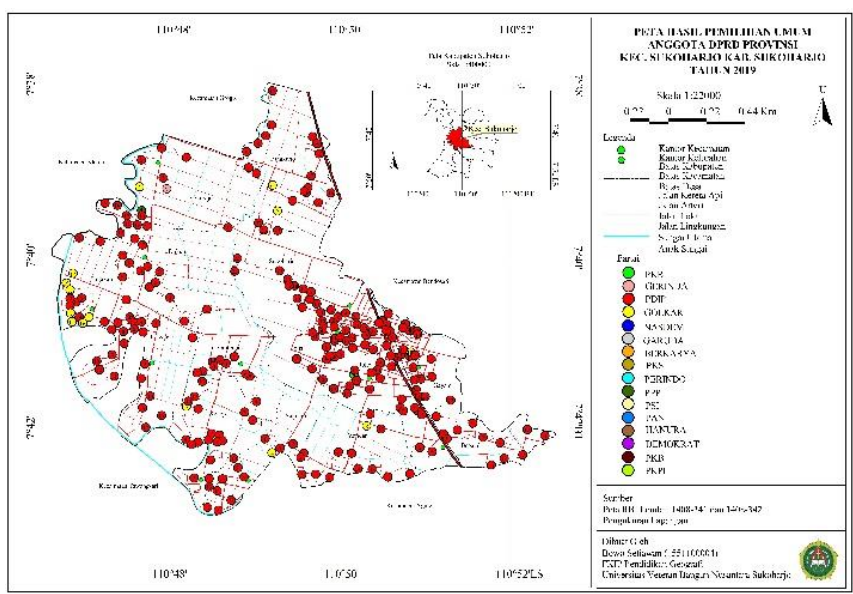

(b)

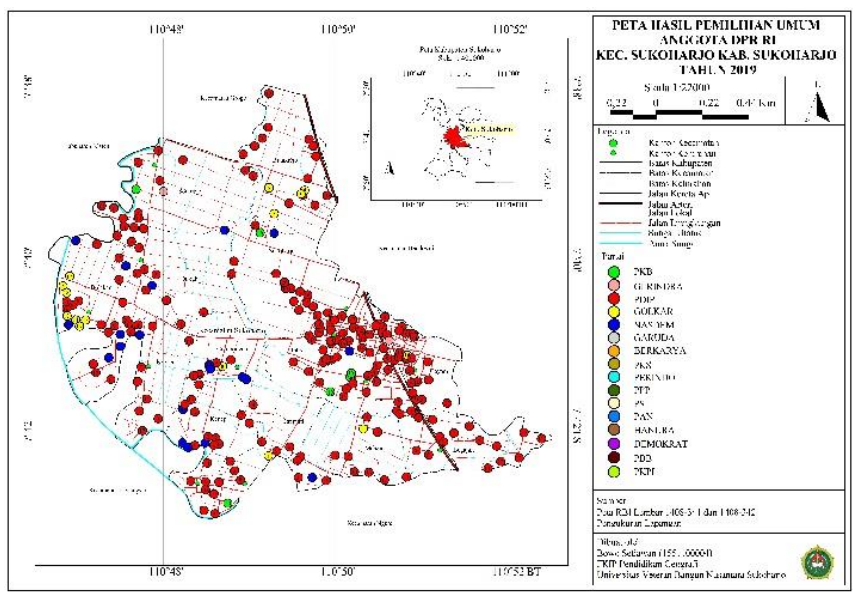

(c)

Figure 3. The Map of Party's Voting Result of a) the Regional House of Representatives Regency of Sukoharjo (DPRD Regency), b) the Regional House of Representatives Province (DPRD Province), and c) the National House of Representatives (DPR RI)

\section{Conclusion}

The distribution of polling stations of the House of Representatives, the Regional House of Representatives Province, and the Regional House of Representatives Regency of Sukoharjo is 252 stations that are distributed over 14 villages which are Sukoharjo, Jetis, Bulakrejo, Banmati, Joho, Dukuh, Gayam, Kenep, Combongan, Kriwen, Mandan, Sonorejo, Begajah, and Bulakan. This distribution is based on the number of inhabitants in each village. 
Sukoharjo village has the largest number of polling stations which is 27 while Gayam village has the least number which is 13 polling stations. Based on the calculation of voting result in all levels of general election, it is found that PDIP party dominates the highest rank in almost all polling stations which is followed by other parties such as lain PKB, GERINDRA, GOLKAR, PERINDO, PKS, PAN, DEMOKRAT, and NASDEM. By comparing the winning rate of each polling station, there are many similarities of party that excels in the vote acquisition of members of the House of Representatives, the Regional House of Representatives Province, and the Regional House of Representatives Regency/City.

\section{Reference}

Andi. 2005. Sistem Informasi Geografi dengan AutoCAD MAP. Yogyakarta: Wahana Komputer Semarang.

Aryono Prihandito, 1989, “Kartografi”, Mitra Gama Widya, Yogyakarta.

Bintarto, R dan Surattopo Hadi Sumarmo. 1987. Metode Analisa Geografi. Jakarta:LP3ES.

Budiardjo, Miriam. 2013. Dasar-Dasar Ilmu Politik. Jakarta: PT Gramedia Pustaka Utama.

Gaffar, Janedjri M. 2013. Demokrasi Dan Pemilu Di Indonesia. Jakarta: Konstitusi Press (KONPRESS).

Juhadi, dan Dewi Liesnoor S. 2001. Desain dan Komposisi Peta Tematik. Semarang: CV.Indoprint.

Kuswanto, Eko. 2018. Pemetaan Fasilitas Kesehatan Badan Penyelengara Jaminan Sosial Kesehatan Kecamata Sukoharjo Kabupaten Sukoharjo. Skripsi.Univet Bantara Sukoharjo.

Marfai, Aris. 2015. Pemodelan Geografi. Yogyakarta: Ombak.

Moleong, Lexy J. 2012. Metode Penelitian Kualitatif. Bandung: PT Remaja Rosdakarya. NN. 2004. Kumpulan Undang-Undang Bidang Politik. Surakarta: PT Pabelan Surakarta.

Rafiani, Minda. 2018. Jangkauan Pemasaran Home Industri Intip Desa Jati Kecamatan Sumberlawang Kabupaten Sragen Tahun 2018 . Skripsi.Univet Bantara Sukoharjo

Setyowati, Dewi Liesnoor dkk. 2014. Kartografi Dasar. Yogyakarta: Ombak.

Soekidjo. 1994. Pengembangan Potensi Wilayah. Bandung. Gramedia 
Sugiyono. 2015. Metode Penelitian Kuantitatif Kualitatif Dan R\&amp;D. Bandung: Alfabeta.

Sugiyono. 2017. Metode Penelitian Kuantitatif Kualitatif. Bandung: Alfabeta.

NN. 2004. Kumpulan Undang-Undang Bidang Politik. Surakarta: PT Pabelan Surakarta.

Triyono. 2013. Metode Penelitian Pendidikan. Yogyakarta: Ombak.

Undang-Undang Republik Indonesia Nomor 7 Tahun 2017 Tentang Pemilihan Umum https://rumahpemilu.org/wp-content/uploads/2017/08/UU-No.7-Tahun-2017tentang-

Pemilu.pdf diakses pada tanggal 29 Januari 2019 Pukul 14.25

Undang-Undang Dasar Negara Republik Indonesia Tahun 1945 http://jdih.pom.go.id/uud1945.pdf diakses pada tanggal 29 Januari 2019 Pukul 14.45 